\title{
Property Rights and Job Security: Workplace Solicitation by Nonemployee Union Organizers
}

The right of self-organization granted employees by section $7^{1}$ of the National Labor Relations Act ${ }^{2}$ includes a right to engage in workplace union solicitation. This activity may be limited only by the employer's managerial needs. ${ }^{3}$ Indeed, employees' solicitation right is considered so essential to self-organization that they may not waive it in a collective bargaining agreement. ${ }^{4}$ Yet the Supreme Court, while recognizing the importance of contact between employees and union organizers for informed exercise of the right of self-organization, ${ }^{5}$ has long insisted upon separate analyses of solicitation by employee and nonemployee union organizers, and has restricted solicitation by recognizing an employer property right only in the latter context.

This Note challenges the rationale underlying the doctrinal distinction between employee and nonemployee solicitation. It argues further that the nonemployee solicitation doctrine fails adequately to value employee job security, by allowing a trivial employer property claim to undermine employees' statutory right to advance their interests through selforganization. In this respect, the nonemployee solicitation doctrine limits the reach of an emerging balance between enhanced employee job security and limited employer property rights reflected in both the administration of the NLRA and the erosion of the doctrine of employment at will.

\section{The Employee and Nonemploye Solicitation Doctrines}

Employees' workplace solicitation right derives from the section 7 right of self-organization, which established collective bargaining as the primary legal means by which employees may protect their employment interests. Job security is clearly a major, if not the principal, interest that employees seek to advance through self-organization. Accordingly, virtually all collective bargaining agreements abrogate the employer's discre-

1. 29 U.S.C. $§ 157$ (1982) provides that: "Employees shall have the right to self-organization, to form, join, or assist labor organizations . . . and to engage in other concerted activities for the purpose of collective bargaining or other mutual aid or protection . . . E" Employer actions held unreasonably to interfere with activities protected by $\S 7$ violate $\S 8(a)(1), 29$ U.S.C. $\S 158(a)(1)(1982)$.

2. 29 U.S.C. $\$ \S 151-169$ (1982) [hereinafter "the Act" or "the NLRA"].

3. Republic Aviation Corp. v. NLRB, 324 U.S. 793, 803 \& n.10 (1945).

4. NLRB v. Magnavox Co., 415 U.S. 322, 324-25 (1974).

5. NLRB v. Babcock \& Wilcox Co., 351 U.S. 105, 113 (1956). 
tionary power to discipline or discharge employees-a power traditionally considered incident to the employer's property right ${ }^{\circ}$ —and impose a "just cause" standard which limits the employer to actions motivated by legitimate managerial concerns. ${ }^{7}$ Collective bargaining further contributes to job security by standardizing promotions, transfers, and layoffs on the basis of seniority. ${ }^{8}$

The Court has interpreted the NLRA to protect union solicitation in order to ensure that employees are able to make an informed choice regarding self-organization. Informed employee choice requires workplace contact between employees and nonemployee organizers. The nonemployee solicitation doctrine thus severely impedes self-organization, sacrificing employee job security to an employer property claim that is obsolete and trivial in comparison with the power of dismissal.

\section{A. Republic Aviation}

The facts of the two cases joined in Republic Aviation Corp. v. NLRB, ${ }^{9}$ in which the Gourt found that section 7 guarantees employees the right to engage in union solicitation on company property, strongly supported a broad policy governing workplace solicitation by employees. In each case, employees were discharged for engaging in union solicitation on company property on their own time, in violation of a company rule against solicitation. Both companies had adopted their rules prior to union activity at the plant, and the rules prohibited all types of solicitation. Further, the employees could not claim that the location of the plants made solicitation off company property impossible. ${ }^{10}$

In sustaining Board orders requiring reinstatement or compensation of the discharged employees, the Court recognized that, because the workplace is a uniquely appropriate site to discuss unionization, freedom of association at the workplace is essential to safeguard the right of selforganization. ${ }^{11}$ The Court accepted the Board's premise that only mana-

6. See infra p. 389.

7. Eighty-three percent of collective bargaining agreements limit discharges by the inclusion of "cause" or "just cause" provisions, 2 Collective Bargatning Negotiations and Contracts (BNA) $\S 40: 1$ (1979), and even where such explicit provisions are absent, "arbitrators read them into the contract as necessarily implied from seniority clauses or grievance and arbitration provisions," Summers, Individual Protection Against Unjust Dismissal: Time for a Statute, 62 VA. L. REv. 481, 499-500 (1976). Under such a standard, the employer must justify discharges on the basis of managerial imperatives.

8. Eighty-nine percent of collective bargaining agreements contain seniority provisions. 2 ColleCtive Bargaining Negotiations and Contracts (BNA) § 75:1 (1983).

9. 324 U.S. 793 (1945).

10. Id. at 794-99.

11. Id. at 801 n.6. See NLRB v. Magnavox Co., 415 U.S. 322, 325 (1974) (workplace is "uniquely appropriate" for discussion of self-organization).

More recently, the Court has clearly indicated that employees' solicitation right guarantees not 
gerial, not property, rights should be considered in evaluating prohibitions of employee solicitation at the workplace, ${ }^{12}$ and adopted the twin presumptions regarding solicitation rules that followed from this premise:

"[A] rule prohibiting union solicitation during working hours ...
must be presumed to be valid in the absence of evidence that it was
adopted for a discriminatory purpose . . [but] a rule prohibiting
union solicitation by an employee outside of working hours, although
on company property ... must be presumed to be an unreasonable
impediment to self-organization and therefore discriminatory in the
absence of evidence that special circumstances make the rule neces-
sary in order to maintain production or discipline."13

Thus the workplace solicitation right established in Republic Aviation is premised upon a distinction between the absolute right of an employer to deny use of company property for union solicitation, which has been abrogated by the NLRA, and the managerial right to impose reasonable limitations on such solicitation in the interest of productivity, which the employer retains under the NLRA. Protection of employee job security rests on the same distinction between the property and the managerial rights of the employer. Job security is achieved through abrogation of the employer's property right of absolute control over job tenure ${ }^{14}$ either as a result of unionization and the imposition of a just cause requirement for dismissal in a collective bargaining agreement ${ }^{15}$ or through the creation of legislative or judicial exceptions to the doctrine of employment at will. ${ }^{16}$ The employer is thus limited to a managerial right of dismissal in the interest of production or discipline, the very right that Republic Aviation protects in the union solicitation context. ${ }^{17}$

merely some, but effective, workplace communication. See Beth Israel Hosp. v. NLRB, 437 U.S. 483, 491 (1978) (employees' $\$ 7$ right to organize and bargain collectively "necessarily encompasses the right effectively to communicate with one another regarding self-organization at the jobsite").

12. 324 U.S. at 797-98. The Court characterized the issue presented by Republic Aviation as the propriety of the Board's "adjustment between the undisputed right of self-organization . . . and the equally undisputed right of employers to maintain discipline in their establishments."

The Court explicitly adopted the Board's policy of limiting the employer's ability to promulgate nosolicitation rules to managerial interests in Republic Aviation, 324 U.S. at 803 n.10. This policy held that although rules forbidding workplace solicitation were valid if needed to avoid disruption of production, Denver Tent \& Awning Co., 47 N.I.R.B. 586, 588 (1943), a rule prohibiting employee solicitation on company time outside of working hours would be presumed invalid absent "special circumstances" demonstrating that the rule was "necessary . . . for the sake of efficiency, discipline, or production." Peyton Packing Co., 49 N.L.R.B. 828, 844 (1943).

13. 324 U.S. at 803 n.10 (quoting Peyton Packing Co., 49 N.L.R.B. 828, 843-44 (1943)).

14. This right is protected by the doctrine of employment at will. See infra p. 389.

15. See supra note 7 and accompanying text.

16. See infra pp. 390-92.

17. Although the Court decisively adopted Board presumptions regarding employee solicitation in Republic Aviation, its rationale remained ambiguous: Was the employer's property right to deny workplace solicitation entirely displaced by employees' $\S 7$ right of self-organization, or only displaced 
The Republic Aviation presumptions are well settled ${ }^{18}$ and strictly enforced. They place a heavy burden on the employer who seeks to demonstrate that special circumstances relating to production or discipline justify a rule against nonworking time employee solicitation, ${ }^{19}$ and render invalid overbroad rules that might silence protected solicitation. ${ }^{20}$ Facially legitimate solicitation rules that companies adopt or enforce so as to discriminate against union solicitation are also invalid. ${ }^{21}$ Nevertheless, strict enforcement of employee solicitation rights has not come at the expense of managerial flexibility. In the context of retail facilities, for example, the Board interprets Republic Aviation as authorizing employers to prevent disruption of their businesses by barring employee solicitation in selling areas during both working and nonworking time. ${ }^{22}$

in the context of workplace solicitation by employees? This ambiguous treatment of employer property rights did not affect application of the Republic Aviation presumptions to employee solicitation; it is implicated, however, in the Court's subsequent formulation of a nonemployee solicitation doctrine and will be discussed in that context, see infra pp. 378-80.

18. Company rules regarding employee workplace solicitation and distribution of literature are now evaluated under standards adopted by the Board in Stoddard-Quirk Mfg. Co., 138 N.L.R.B. 615 (1962), pursuant to Republic Aviation. The standards accord presumptive validity to rules forbidding employee distribution of union literature in work areas during either working or nonworking time and to rules forbidding employee solicitation during working time in any plant area; they hold presumptively invalid rules forbidding the distribution of union literature in nonwork areas during nonworking time and rules forbidding union solicitation during nonworking time. Jarvis, Organizational Campaigns: Privale Rights vs. Public Rights, in ProceEdINgs OF NEw YoRK UNIVERSITY Twenty-Sixth ANnual Conference on Labor 3, 4 (1974).

Courts in all circuits acknowledge the continued validity of the Republic Aviation presumptions. See Eastern Maine Medical Center v. NLRB, 658 F.2d 1, 4 (1st Cir. 1981); NLRB v. Miller, 341 F.2d 870, 873-74 (2d Cir. 1965); Graham Architectural Prods. Corp. v. NLRB, 697 F.2d 534, 541-42 (3d Cir. 1983); Virginia Elec. \& Power Co. v. NLRB, 703 F.2d 79, 81-82 (4th Cir. 1983); Marathon LeTourneau Co. v. NLRB, 699 F.2d 248, 256 (5th Cir. 1983); Union Carbide Corp. v. NLRB, 714 F.2d 657, 663 (6th Cir. 1983); Midwest Stock Exch. v. NLRB, 635 F.2d 1255, 1270 (7th Cir. 1980); NLRB v. Chem Fab Corp., 691 F.2d 1252, 1258 (8th Cir. 1982); NLRB v. Silver Spur Casino, 623 F.2d 571, 582 (9th Cir. 1980); Coors Container Co. v. NLRB, 628 F.2d 1283, 1286 (10th Cir. 1980); NLRB v. Lummus Indus., 679 F.2d 229, 233 (11th Cir. 1982); Road Sprinkler Fitters v. NLRB, 681 F.2d 11, 21 (D.C. Cir. 1982), cert. denied sub nom. John Cuneo, Inc. v. NLRB, 459 U.S. 1178 (1983).

19. See Coors Container Co. v. NLRB, 628 F.2d 1283, 1286 (10th Cir. 1980) (employer's "mere assertion" that special circumstances exist insufficient to justify curtailment of employee's guaranteed rights).

20. See, e.g., Utrad Corp. v. NLRB, 454 F.2d 520, 523-24 (7th Cir. 1971) (rule prohibiting solicitation absent prior approval by personnel department invalid, though unenforced, because of chilling effect on protected solicitation); NLRB v. Linda Jo Shoe Co., 307 F.2d 355, 357 (5th Cir. 1962) (posted rule absolutely prohibiting solicitation on company premises invalid despite employer's statement that rule applied to worktime solicitation only).

21. See Revere Camera Co. v. NLRB, 304 F.2d 162, 165 (7th Cir. 1962) (facially valid nosolicitation rule adopted after start of union campaign and enforced only against pro-union solicitation held invalid).

22. See McDonald's Corp., 205 N.L.R.B. 404, 407-08 (1973) (upholding rule forbidding employee solicitation in selling area of retail food outlet). The origin of this policy is the Board's decision in May Dep't Stores Co., 59 N.L.R.B. 976, 981 (1944), enforced, 154 F.2d 533 (8th Cir.), cert. denied, 329 U.S. 725 (1946). The exception applies to any "retail business where customers deal directly with the employees," Goldblatt Bros., 77 N.L.R.B. 1262, 1271 (1948) (upholding rule forbidding employee solicitation on selling floor of department store restaurant open to both public and employees). 


\section{B. Babcock}

Despite the strong policy in support of broad solicitation rights established by Republic Aviation and its progeny, the Supreme Court, in $N L R B$ v. Babcock \& Wilcox Co., ${ }^{23}$ refused to apply the Republic Aviation presumptions to workplace solicitation by nonemployee organizers. ${ }^{24}$ Under the Babcock formula, companies may deny nonemployee union organizers the most effective means of communication-workplace solicitation ${ }^{25}$ - "if reasonable efforts by the union through other available channels of communication will enable ... [it] to reach the employees with ... [its] message."26

The nonemployee access challenged in the cases joined in Babcock had not extended beyond company parking lots. The employers did not claim that such access threatened plant management; rather, in the absence of managerial concerns, they claimed a property right to deny access to nonemployees. Disposition of this claim turned on the rationale underlying Republic Aviation. Prior to Babcock, the NLRB had adopted a policy of applying Republic Aviation's twin presumptions to workplace solicitation by employees and nonemployees alike. The Board implicitly interpreted the opinion to hold that the NLRA had entirely displaced employers' property right to control access whenever such access is sought for purposes of union solicitation-limiting the employer to a managerial interest in regulating the extent of workplace solicitation.

In supporting the employers' claim, the Babcock Court repudiated the Board's interpretation of Republic Aviation. The Court discovered a distinction "of substance"27 between solicitation by employees and nonemployees: Employers owe no obligation to nonemployee organizers under the Act. ${ }^{28}$ Thus Babcock held that recognition of an employer property right to deny access to company property for union solicitation turns on whether those engaged in the solicitation possess section 7 rights. ${ }^{29}$

What the Court failed to recognize was that while nonemployee union organizers do not possess section 7 rights, they are employees' principal

23. 351 U.S. 105 (1956).

24. Id. at 113. Prior to the Court's decision in Babcock, the Board had applied the Republic Aviation presumptions to rules governing solicitation by employees and nonemployees alike. See Hanley, Union Organization on Company Property-A Discussion of Property Rights, 47 GEo. L.J. 266, 295 (1958).

25. See supra note 11 and accompanying text; see also Eastex, Inc. v. NLRB, 437 U.S. 556, 574 (1978) (workplace is particularly appropriate location for distribution of union literature); $c f$. Gould, Union Organizational Rights and the Concept of "Quasi-Public" Property, 49 MinN. L. REv. 505, 513 (1965) (workplace is "focal point" of organizational effort because of inherent difficulties in use of other meeting places).

26. 351 U.S. at 112 .

27. Id. at 113 .

28. Id. at 113-14.

29. Id. 
source of pro-union information during a representation campaign. Thus the question presented in Babcock was not whether nonemployees had a right to engage in workplace solicitation, but whether employees' section 7 right of self-organization encompassed a right to workplace contact with nonemployee organizers. Moreover, the NLRB had long ago decided that section 7 grants employees the right not only to speak but "to receive aid, advice, and information from others" concerning self-organization. ${ }^{30}$ While the Babcock Court recognized that informed employee choice depends upon communication with professional organizers, ${ }^{31}$ it assumed that the right of self-organization could in most cases be adequately protected by contact off company property. ${ }^{32}$ This failure to appreciate the importance of contact at the workplace between union organizers and employees and the inadequacy of alternative means of communication ${ }^{33}$ prevented the Court from concluding, with the Board, that employees' solicitation right necessitated abridgement of the property right to deny access to nonemployee organizers. ${ }^{34}$

The Court has recently offered a new rationale for Babcock's distinction between employee and nonemployee solicitation, stating that the property claim was upheld in Babcock because it was asserted against trespassers, rather than against employees who had been invited onto company property by the employer. ${ }^{35}$ The Court has thus come to view Babcock as resting on a distinction in status between employees and nonemployees, not as possessors or nonpossessors of section 7 rights, but as invitees or trespassers against whom the employer retains a property right of exclusion. ${ }^{36}$

The texts of Republic Aviation and Babcock do not support this formulation of the distinction between employee and nonemployee solicitation. ${ }^{37}$

30. Harlan Fuel Co., 8 N.L.R.B. 25, 32 (1938).

31. 351 U.S. at 113 .

32. Id. at $112-13$.

33. See Note, Still as Strangers: Nonemployee Union Organizers on Private Commercial Property, 62 Tex. L. Rev. 111, 151-52 (1983) (Babcock Court erroneously assumed efficacy of alternative channels of communication).

34. Cf. Bredhoff, Forum: Labor Law Reform: A Labor Perspective, 20 B.C.L. REv. 27, 32 (1978) ("T The thirty year history of litigation concerning rights of access for employees and organizers reveals that the limitations on those rights have stemmed not from the requirements of the Act, but from unfounded assumptions as to the effectiveness of alternative channels of communication.").

35. Eastex, Inc. v. NLRB, 437 U.S. 556 (1978).

36. In Easlex the Court stated:

The difference was that the nonemployees in Babcock $\&$ Wilcox sought to trespass on the employer's property, whereas the employees in Republic Aviation did not . . . . The Court recently has emphasized the distinction between the two cases: "A wholly different balance was struck when the organizational activity was carried on by employees already rightfully on the employer's property, since the employer's management interests rather than his property interests were there involved."

437 U.S. at 571-72 (quoting Hudgens v. NLRB, 424 U.S. 507, 521-22 n.10 (1976)).

37. It appears, however, that the author of both Republic Aviation and Babcock, Justice Reed, may have had this distinction in mind. Compare the Court's interpretation of Republic Aviation in 
Nor does an invitee-trespasser distinction make sense given the nature of the employer's claim. The employer is asserting a property right to control not merely access to, but more importantly use of, company property. Both employee and nonemployee solicitation threaten this property right. The artificial invitee-trespasser distinction thus veils the fact that, from the point of view of the employer, all workplace solicitation is trespass. ${ }^{38}$

The invitee-trespasser distinction is equally incoherent with respect to the Court's holding in Republic Aviation. Had the Court thought that the employer's invitation to employees included a waiver of the right to prohibit workplace solicitation, it could simply have dismissed the employers' claims on that basis; the creation of an employee right of self-organization in the NLRA would not have been decisive. ${ }^{39}$ Rather than so holding, the Court determined that employees' right of self-organization abridged the employer's property right to deny use of the workplace for union solicitation.

Republic Aviation does, however, recognize an employer's managerial right to regulate solicitation in the interest of discipline, production, or safety. As applied to solicitation by nonemployee organizers, Republic Aviation would authorize denial of access in circumstances where access truly posed a threat of disruption to the employer's business. The argument that Babcock rests on an invitee-trespasser distinction is thus reduced to the implausible assertion that control over access to company premises, in the absence of concern over disruption or safety, is not only a more important property right than control over use of the premises, but is more important than employees' section 7 rights. ${ }^{40}$

Marsh v. Alabama, 326 U.S. 501, 506 (1946) (owner's property right was circumscribed by statutory grant of right of self-organization to employees) with Justice Reed's dissent in the same case, id. at 515 (recognition of statutory right in Republic Aviation was dependent upon employees' status as licensees).

38. Justice Rehnquist makes this point in his dissent in Eastex, 437 U.S. at 581-82 n.1. Indeed the Court has made this very point in another context. See Lloyd Corp. v. Tanner, 407 U.S. 551, 564-65 (1972) (shopping mall owner's invitation to public is limited to owner's commercial purpose).

39. Cf. Note, supra note 33, at 163-64 (employees had no more right to workplace solicitation at common law than nonemployees).

40. The view that $B a b c o c k$ rests on an invitee-trespasser distinction has led to a limitation of the solicitation rights of off-duty employees, whose activity, absent this reformulation of Babcock, would have been protected by Republic Aviation. Courts adopting the invitee-trespasser distinction have held that since off-duty employees are no longer invitees, they and nonemployees are similarly situated. See McDonnell Douglas Corp. v. NLRB, 472 F.2d 539, 547 (8th Cir. 1973); Diamond Shamrock Co. v. NLRB, 443 F.2d 52, 58 (3d Cir. 1971); Jarvis, supra note 18, at 12. The courts' position forced the Board to reverse its earlier view that Republic Aviation governed off-duty employee solicitation and to hold that Babcock's alternative channels of communication standard would apply. GTE Lenkurt, Inc., 204 N.L.R.B. 921, 921-22 (1973).

The Board has since acknowledged that application of the invitee-trespasser distinction forces workplace solicitation among employees-the very activity protected by Republic Aviation-to yield to an employer property claim merely because the employees work separate shifts, and has adopted a compromise position under which a rule forbidding access by off-duty employees is valid "only if it ... limits access solely with respect to the interior of the plant and other working areas ...." Tri-County 


\section{The Babcock Doctrine Applied}

Babcock's protection of employer property rights in the context of nonemployee solicitation seriously compromises the right of access to information granted employees in Republic Aviation. ${ }^{41}$ Broad application of Babcock's alternative channels of communication test, designed to protect employers' property rights, has undermined employees' section 7 right to protect their jobs via self-organization. Use of the test has sharply curtailed employees' communication with nonemployee organizers, the critical source of pro-union information during a representation campaign, and granted employers the exclusive right to make speeches to the captive audience of employees at the workplace. ${ }^{42}$

The doctrine developed under Babcock rests on a nearly irrebuttable presumption against nonemployee access to company property. ${ }^{43}$ This

Medical Center, Inc., 222 N.L.R.B. 1089, 1089 (1976). Rules forbidding off-duty employee access to outside, nonworking areas such as parking lots or gates are invalid unless "justified by business reasons." Id.

This compromise makes little sense as a matter of doctrine and offers inadequate protection of separate-shift employee solicitation. If the policy is designed to protect managerial rather than property interests of the employer, there is no reason to deny off-duty employees (or nonemployees) the right to solicit in interior plant areas on the same terms-under Republic Aviation-as employees who are on duty. Alternatively, if the critical boundary of the protected employer property interest is thought to be the plant wall, there is no reason not to permit nonemployee solicitation on parking lots and at gates as well. Furthermore, the Board's compromise may permit distribution of union literature by off-duty employees to those working different shifts (as the latter arrive for or leave work) but will not permit adequate discussion of self-organization between such groups of employees for, as the Court and the Board have recognized, see supra note 11, such discussion occurs within the plant during rest periods.

41. See Zimny, Access of Union Organizers to "Private" Property, 25 LAB. L.J. 618, 624 (1974):

Realization of [the right of self-organization] requires a maximum opportunity for effective communication with employees. But to elevate property rights over the personal rights guaranteed by the Act, as the Board and the Courts have largely done in their repeated denial of the right of nonemployee organizers to effectively communicate with workers, frustrates fulfillment of federal law in the most basic way.

Empirical support for this proposition is discussed infra note 48 .

In NLRB v. United Steelworkers of America (Nutone, Inc.), 357 U.S. 357 (1958), Chief Justice Warren asserted that, because of the importance of use of the workplace for organization, denial of access to the union by an employer engaged in coercive campaigning would itself constitute an unfair labor practice. Id. at 368-69 (Warren, C.J., dissenting in part and concurring in part); $c$. Barron, $A$ Theory of Protected Emplojer Rights: A Revisionist Analysis of the Supreme Court's Interpretation of the National Labor Relations Act, 59 TEx. L. REv. 421, 439 (1981) (arguing that decision to recognize a property claim as against nonemployee solicitation "effectively . . . creat[ed] an employer right that the NLRA arguably had extinguished").

42. Several commentators argue that Babcock has resulted in an erosion of the employee solicitation right. See Bredhoff, supra note 34, at 27-28; Gould, supra note 25, at 512; Zimny, supra note 41 , at 619-20, 624.

43. Despite the Court's assertion in Babcock that "[a]ccommodation between $[\S 7$ and property rights] must be obtained with as little destruction of one as is consistent with the maintenance of the other," 351 U.S. at 112, its holding that an employer may exclude nonemployee organizers where alternative means of contacting employees exist, $i d$., established a clear presumption in favor of the employer and placed a heavy burden on the union to justify displacement of the property right. See Note, NLRB Orders Granting Unions Access to Company Property, 68 CoRnell L. Rev. 895, 902 (1983) ("[A]lmost any degree of contact establishes the existence of alternative means of access.").

The Court has recently resurrected Babcock's principle of accommodation in the context of strike 
presumption results from the courts' broad application of Babcock, which deems "reasonable" alternative channels of communication available to the union, such as home visits, correspondence, and advertising campaigns, in all but exceptional cases. ${ }^{44}$ In 1975, Board Member Fanning, reviewing the application of the Babcock standard, concluded that "[g]enerally speaking, an employer . . . can prohibit union solicitation or distribution by non-employees at any time and anywhere on his property."45

Babcock's presumption against union access enables employers to create an informational imbalance in their favor by using the most effective forum for solicitation, the workplace, to deliver "captive audience" speeches without giving union organizers a similar opportunity. ${ }^{46}$ In this way, re-

activity on quasi-public property (such as shopping malls or office buildings), suggesting that proper accommodation in a given case depends upon the nature of the $\S 7$ activity at issue. Hudgens $v$. NLRB, 424 U.S. 507, 522 (1976).

The result of flexible application of Babcock in the context of nonorganizational $\S 7$ activity is that, because of the traditional strict application of Babcock's presumption against access for purposes of solicitation, see infra notes 44-46 and accompanying text, the Board may now grant access to quasipublic property more freely for strike activity than for organizational solicitation. Compare SeattleFirst Nat'l Bank v. NLRB, 651 F.2d 1272, 1276-77 (9th Cir. 1980) (owner of office building violates $\S 8(\mathrm{a})(1)$ by threatening to arrest both employees and nonemployees picketing, in support of strike, in foyer of restaurant on forty-sixth floor) with Hutzler Bros. v. NLRB, 630 F.2d 1012, 1016-18 (4th Cir. 1980) (operator of department store does not violate $\S 8(\mathrm{a})(1)$ by threatening to arrest nonemployee organizers engaged in solicitation at store entrances, in absence of showing that union had no other reasonable means of communicating with employees). Cf. O'Connor, Accommodating Labor's Section 7 Rights to Picket, Solicit, and Distribute Literature on Quasi-Public Property with the Owners' Property Rights, 32 Mercer L. Rev. 769, 789 (1981) (despite flexibility in accommodating $\$ 7$ and property rights authorized in Hudgens, if protected activity at issue is organizational solicitation "the test as stated in Babcock $\mathcal{F}$ Wilcox is still controlling"). This result cannot be justified as protecting either important $\S 7$ or property rights, for it is the policy of the Act to prevent strike activity (at issue in Hudgens), through collective bargaining (see United Steelworkers of America v. Warrior \& Gulf Navigation Co., 363 U.S. 574, 578 (1960)), while solicitation is necessary to enable employees to exercise the right of self-organization, which is the centerpiece of federal labor policy.

44. Zimny, supra note 41 , at 620-21. Exceptions are exceedingly rare. Note, supra note 43 , at 902. See Husky Oil v. NLRB, 669 F.2d 643, 647-48 (10th Cir. 1982) (remote Alaskan worksite; Board access order enforced).

While the Board has been more lenient in the context of resorts with live-in employees, the courts typically have denied enforcement of access orders in such cases because the union could not demonstrate the impossibility of using alternative means to establish contact with the employees. See NLRB v. Tamiment, Inc., 451 F.2d 794, 799 (3d Cir. 1971), cert. denied, 409 U.S. 1012 (1972); NLRB v. Kutsher's Hotel \& Country Club, 427 F.2d 200, 201 (2d Cir. 1970). Note, supra note 43, at 903.

45. Fanning, Union Solicitation and Distribution of Literature on the Job-Balancing the Rights of Employers and Employees, 9 GA. L. REv. 367, 371 (1975). The Court has also acknowledged that "the balance struck by the Board and the courts under the Babcock accommodation principle has rarely been in favor of trespassory organizational activity." Sears, Roebuck \& Co. v. San Diego County Dist. Council of Carpenters, 436 U.S. 180, 205 (1978).

46. This rule was established by the Board in Livingston Shirt Corp., 107 N.L.R.B. 400, 409 (1953). Its impact on representation campaigns is suggested infra note 48.

The employer may deliver a captive audience speech under circumstances that violate a company rule against solicitation, yet invoke Babcock to deny the union access. NLRB v. United Steelworkers of America (Nutone, Inc.), 357 U.S. 357, 363-64 (1958) (enforcement of otherwise valid rules prohibiting employee solicitation by employers who engaged in workplace anti-union solicitation does not constitute unfair labor practice absent showing that "the no-solicitation rules truly diminished the ability of the labor organizations involved to carry their messages to the employees"). 
stricting employee access to pro-union information on company premises during a representation campaign undermines the statutory goal of informed employee choice.

The only empirical study of representation campaigns to date ${ }^{47}$ confirms that employer monopolization of the workplace as a location for campaign meetings is critical to employers' success in defeating employee self-organization. ${ }^{48}$ Given employers' increased advantage over unions in exposing employees to their campaigns, and increasingly sophisticated employer campaign tactics, it is hardly surprising that the proportion of elections won by unions has steadily declined since the Court's decision in Babcock.48

The NLRB has authority to grant limited union access to company bulletin boards or parking lots when the employer commits unfair labor practices during the campaign. Such remedial orders, however, are uncommon and are typically enforced only upon substantial evidence of extreme or repeated abuses by the employer. Decaturville Sportswear Co. v. NLRB, 406 F.2d 886, 888-89 (6th Cir. 1969) (order granting limited access to parking lots and bulletin boards enforced where employer prevented union distribution of literature on adjacent public property, kept employees under surveillance and photographed those taking union literature, forced organizers' cars off highway, and threatened organizers with physical injury), see also Textile Workers Union v. NLRB (J.P. Stevens), 388 F.2d 896 (2d Cir. 1967), cert. denied, 393 U.S. 836 (1968); Florida Steel Corp. v. NLRB, 620 F.2d 79 (5th Cir. 1980).

47. J. Getman, S. Goldberg \& J. Herman, Union Representation Elections: Law \& REALITY (1976) [hercinafter cited as UNION REPRESENTATION Elections].

48. Employees reported roughly equivalent exposure to company and union written campaign material, id. at 90 , while neither management representatives nor pro-union employees engaged in extensive personal solicitation at work. Id. at 93-94. Union organizers reported a disinclination to use home visits as an organizing tactic because of geographical dispersion and the difficulty of competing with other activities of the employees. Id. at 94-95. The meeting emerged as the means of communication that correlated most directly with employee familiarity with a party's campaign. Id. at 91, 95-96. Campaign familiarity, in turn, correlated with a pro-union vote: While company and union voters tended to be equally familiar with the employer's campaign, union voters were "significantly more familiar with the union's campaign than were company voters." Id. at 85 . This contrast appeared most significantly with respect to employees who switched their vote as a result of the campaign. Id. at 103-04. The authors comment that "[t]he apparent reason why the switchers and the undecided who voted union knew significantly more about the union campaign was that they attended union meetings more frequently," id. at 104, and conclude:

The employer's advantage is primarily due to the powerful correlation between campaign familiarity and attendance at meetings. ... The employer tends to be far more successful in attracting employees to meetings on working time and premises than does the union in attracting them to meetings outside working hours and away from company premises. Eightythree percent of the sample attended company meetings, while only 36 percent attended union mectings. Furthermore, those employees who attended union meetings tended to be union supporters. The company, then, has a great advantage in communicating with the undecided and those not already committed to it. This advantage is particularly important since attendance at union meetings is significantly related to switching to the union.

Id. at 156-57. Cf. Bredhoff, supra note 34, at 32-33 (combination of Babcock doctrine and captive audience speech creates "unjustifiable imbalance" favoring employer's campaign).

49. The union victory rate fell from $74 \%$ in 1950 to $61 \%$ in 1965 and $48 \%$ in 1980 . Weiler, Promises to Keep: Securing Workers' Rights to Self-Organization under the NLRA, 96 HARv. L. REV. 1769, 1775-76 (1983). The result was a decline in the proportion of organized nonagricultural workers from nearly $35 \%$ in 1954 to just over $20 \%$ in 1980 . Id. at $1771-72$. Weiler rejects the claim that declining employee enthusiasm for unionism is responsible for this trend and, like the authors of UNION REPRESENTATION ELECTIONS, supra note 47, argues that it is the result of Board administration of representation campaigns. Weiler, supra, at 1773-74 \& n.6, 1776-77. Weiler's concern, how- 


\section{Job SECURITY UNDER THE NLRA}

By denying employees meaningful contact with the principal source of pro-union information, Babcock severely burdens employees' right to seek job security through self-organization. The current assault on employers' property right to discharge unorganized employees at will, discussed in Part III, rests on a contemporary recognition of the need to reverse $B a b$ cock's priorities, and to protect job security by prohibiting the employer from acting in the absence of a legitimate managerial concern. Babcock also runs counter to the policy of enhancing the job security of unionized employees reflected in limitations imposed on employer speech and union organizational rights in the administration of the NLRA.

\section{A. Employer Speech Rights}

Despite the Supreme Court's repeated assertions that the First Amendment protects full and open debate, ${ }^{50}$ it has enforced restrictions on em-

ever, is not union access to employees during the campaign, but coercive employer campaign tactics. In opposition to the conclusions in UNION REPRESENTATION Elections, see infra note 55, Weiler identifies employers' coercive tactics as the primary obstacle to employee self-organization. Weiler, supra, at $1772-74,1776-77,1781$. Whether the cause of declining employee unionization is employer coercion, employer promises of concessions, fear of job loss, or changed economic and political attitudes, it is reasonable to assume that workplace contact between union organizers and employees and redress of the imbalance favoring access to the employer's campaign would counteract these influences and strengthen pro-union sentiment.

Labor leaders' opposition to the Babcock doctrine led to the inclusion of an equal access provision in the proposals to amend the Act considered during the 95th Congress, see H.R. 8410, 95th Cong., 1st Sess. § 3, 123 Cong. Rec. 32482-83 (1977); S. 2467, 95th Cong., 2nd Sess. § 4, 124 Cong. Rec. 13812 (1978); the House bill passed, but the Senate bill did not. It is unclear to what extent the equal access rule blocked Senate passage of the labor law reform bill. In a post-defeat debate of the equal access issue, however, the management spokesman suggested that the bills were perceived as unfair because while they urged the equal access rule on the basis of UNION REPRESENTATION ElEcTIONS, supra note 47 , see infra note 91 , the bills failed to include the authors' companion recommendation that the Board deregulate employer campaign activity. Kramer, Forum: Labor Law Reform: A Management Perspective, 20 B.C.L. REv. 4, 9 (1978).

50. See, e.g., First Nat'l Bank v. Bellotti, 435 U.S. 765, 777 (1978) (corporate identity of speaker is impermissible basis for regulation of speech that limits public's access to information essential for democratic decisionmaking); Red Lion Broadcasting Co. v. FCC, 395 U.S. 367, 390 (1969) (First Amendment protects public right to "uninhibited marketplace of ideas" against monopolization by broadcasters); New York Times Co. v. Sullivan, 376 U.S. 254, 270 (1964) (First Amendment embraces "profound national commitment to the principle that debate on public issues should be uninhibited, robust, and wide-open"); cf. Getman, Labor Law and Free Speech: The Curious Policy of Limited Expression, 43 MD. L. REv. 4 (1984) (discussing Supreme Court's departure from general First Amendment standards in labor context); Christensen, Free Speech, Propaganda and the National Labor Relations Act, 38 N.Y.U. L. REv. 243, 246 (1963) (increased regulation of speech under NLRA threatens constitutional rights of the regulated).

Outside of the labor context, the Court generally refuses to assume that speech will have a coercive impact. NAACP v. Claiborne Hardware Co., 458 U.S. 836, 915-20 (1982); Organization for a Better Austin v. Keefe, 402 U.S. 415, 419 (1971). Getman, supra, at 10, contrasts the Court's rejection of government officials' claims to be able to predict the impact of speech on listeners, e.g., Virginia State Bd. of Pharmacy v. Virginia Citizens Consumer Council, 425 U.S. 748, 769-70 (1976); Cohen v. California, 403 U.S. 15, 23-24 \& n.5 (1971), and its insistence that speech not be characterized as unlawful absent clear threats of imminent violence, Brandenburg v. Ohio, 395 U.S. 444, 447 (1969), 
ployer speech during union representation campaigns. These restrictions are imposed by the Board in an effort to prevent coercion from undermining employee efforts to organize. Section $8(c)$ of the Act ${ }^{51}$ theoretically incorporated First Amendment protection for employer campaign activity by limiting the range of expression that could be considered an unfair labor practice to "threat[s] of reprisal or force or promise[s] of benefit." However, the standard developed under this provision treats the prohibition expansively. Employer remarks concerning the effect of unionization will be considered unprotected threats unless they are "carefully phrased on the basis of objective fact to convey an employer's belief as to demonstrably probable consequences beyond his control."152 Should the union lose, such threats subject the employer to a rerun election or a bargaining order. ${ }^{53}$ Moreover, merely conferring economic benefits on employees during a campaign may subject the employer to similar consequences. ${ }^{54}$

These restrictions on employer speech are particularly striking given the lack of a proven correlation between unlawful employer campaign tactics and employee voting behavior. ${ }^{56}$ In curtailing employer First Amendment rights on the basis of a speculative notion of coercion, the Court places great value on employees' right to seek job protection through selforganization. Yet Babcock seriously compromises this right on behalf of a trivial employer property right. Because it permits employers to control merely access to, but not use of, company property, the nonemployee solicitation doctrine in fact serves little purpose other than that of frustrating employee self-organization. ${ }^{56}$

\section{B. Union Organizational Rights}

The NLRA does more to protect employee job security than merely regulate representation campaigns. By organizing, employees effectively abrogate the employer's property right of absolute control over job tenure. Their collective bargaining agreement protects them against discipline or discharge for other than legitimate managerial reasons, and replaces em-

with the ready assumption of coercive impact in the labor speech context.

51. 29 U.S.C. \& 158(c) (1982).

52. NLRB v. Gissel Packing Co., 395 U.S. 575, 618 (1969).

53. Id. at 614-15.

54. NLRB v. Exchange Parts Co., 375 U.S. 405, 409 (1964).

55. The authors of UNION REPRESENTATION Elections, supra note 47, concluded on the basis of their research that unlawful employer campaign tactics had no effect on employee voting, giving rise to a continuing debate discussed, most recently, in Weiler, supra note 49 , at 1782 \& n.39. Weiler's claim that the declining union victory rate is due primarily to coercive employer campaign tactics, $i d$. at 1781 , relies on analysis of the data reported in UNION REPRESENTATION ELECTIONS, id. at 1784 n.50, by W. Dickens, Union Representation Elections: Campaign and Vote (Oct. 1980) (unpublished Ph.D. dissertation, Department of Economics, Massachusetts Institute of Technology).

56. Cf. Note, supra note 33, at 167-71 (Babcock protects "purely dignitary property interest that cannot be justified as providing efficiency, liberty, or personal identity"). 
ployer discretion concerning promotions and transfers with a seniority system. In the administration of this agreement, however, conflicts may arise between an individual employee's job security interests and the rights of the union. While resolution of such conflicts in favor of the individual could conceivably interfere with the job security of employees as a group, courts have preferred to promote employee job security at the expense of union rights in each of the following contexts.

\section{Union Speech}

Employee challenges to certain expenditures of dues by certified bargaining agents have led courts to impose a heavy burden on union political speech. In Abood v. Detroit Board of Education, ${ }^{57}$ the Court held that a union violated the First Amendment rights of employees by spending a portion of the dues it had collected pursuant to an agency shop agreement for political contributions to which the employees objected and which the Court found to be unrelated to the union's statutory duties as collective bargaining agent. ${ }^{58}$ The decision does more than protect First Amendment rights of employees. By holding that an employee must not be forced to choose between speech rights and continued employment, ${ }^{88}$ Abood acknowledges the value of and protects employee job security, ${ }^{60}$ despite the serious cost to the union. ${ }^{61}$

\section{Union Membership Requirements}

The Board has enhanced employee job security by interpreting the NLRA to protect union members against discipline or discharge by the employer at the union's insistence for violation of any union membership requirement other than payment of dues. ${ }^{62}$ This policy affords employees the greatest degree of job security consistent with protection of the union's financial base. It clearly burdens the union's ability effectively to enforce

57. 431 U.S. 209 (1977).

58. Id. at $235-36$.

59. Id. at 235: "[First Amendment principles] prohibit the appellees from requiring any of the appellants to contribute to the support of an ideological cause he may oppose as a condition of holding a job as a public school teacher."

60. The weight that the Court gave to employee job security in limiting union speech is illustrated by the contrast between Abood and the Court's decision the following year in First Nat'l Bank v. Bellotti, 435 U.S. 765 (1978), wherein the Court refused to uphold limitations on corporate speech on the basis of an asserted state interest in protecting the First Amendment rights of dissenting shareholders. Id. at 792-95.

61. The Court admitted that "difficult problems" would attend the "drawing [of] lines between collective bargaining activities . . . and ideological activities unrelated to collective bargaining." 431 U.S. at 236. In fact, the traditional inseparability of union political and economic activities makes the Abood rule a fertile source of litigation for anti-union employees and, therefore, an onerous and expensive liability for unions.

62. Radio Officers' Union v. NLRB, 347 U.S. 17, 40-42 (1954). 
its membership requirements, in the interest of protecting employee job security.

\section{Duty of Fair Representation}

The most extensive burdening of union associational freedom in the interest of employee job security has come with the expansion of unions' duty of fair representation. ${ }^{.3}$ This duty, originally a protection of unit members excluded from membership against invidious discrimination by the union, ${ }^{64}$ has expanded into a broad and ill-defined responsibility that a union nonarbitrarily represent the interests of all unit members during contract administration. ${ }^{68}$ At least one lower court has interpreted the Supreme Court's admonition that a union "may not arbitrarily ignore a meritorious grievance or process it in a perfunctory fashion"68 as transforming the duty into a prohibition of mere negligent union representation. ${ }^{67}$ Such a prohibition imposes serious constraints upon the union's freedom to structure its system of grievance management, in order to protect employee job security. It seeks to prevent union mismanagement of the grievance of an improperly disciplined or discharged employee from causing the individual's contract claim against the employer to lapse.

In the regulation of representation elections and contract administration under the NLRA, the Board and the courts place great importance on job security, and are willing to burden competing rights of unions and employers. Continued recognition of a near-absolute employer property right to deny access to union organizers is a particularly costly exception to this commitment to the protection of job security in representation campaigns and contract administration. It frustrates informed employee choice regarding unionization, thus impeding efforts to gain job security through the means provided by the NLRA.

\section{Job Security and Employment At Will}

The protection of unionized employees discussed in Part II mirrors a growing appreciation in scholarship ${ }^{68}$ and caselaw of the importance of

63. The origin of this duty is the Court's opinion in Steele v. Louisville \& Nashville R.R. Co., 323 U.S. 192, 204 (1944), holding that a union may not use its status as bargaining agent to discriminate against black employees in contract negotiation.

64. The Steele Court analogized the union's duty to that of a legislature "to give equal protection to the interests of those for whom it legislates." Id. at 202.

65. Vaca v. Sipes, 386 U.S. 171, 190 (1967).

66. Id. at 191 .

67. See Ruzicka v. General Motors Corp., 523 F.2d 306, 310 (6th Cir. 1975) (failure of union official to file arbitration papers on time violates duty of fair representation). For a discussion of the current standard for liability under Vaca, see Comment, Breaching the Duty of Fair Representation: The Union's Liability, 17 J. Mar. L. REv. 415, 422-23 (1984).

68. Berle, Property, Production and Revolution, 65 Colum. L. Rev. 1, 20 (1965) (predicting "a 
extending job security to unorganized employees. Such protection necessarily entails abrogation of the employer's absolute property right to control job tenure. Thus the current revaluation of employment rights inverts Babcock's priorities; it sacrifices an employer property right to employee job security (while preserving the employer's managerial authority to discharge an employee for cause).

This reconception of employment rights rests on two premises. The first is that, for the vast majority of Americans, jobs are the principal source of wealth and status, ${ }^{69}$ and have replaced traditional forms of property as the material basis of individual liberty. ${ }^{70}$ The second is that gross inequality of bargaining power prevents unorganized employees from achieving job security. ${ }^{71}$ These premises are most frequently advanced in the large body of literature ${ }^{72}$ advocating abandonment of the rule, applicable to all em-

growing demand that significant jobs be available for everyone"); Reich, The New Property, 73 Yale L.J. 733 (1964) (expanded notions of property rights necessary to ensure employees' personal autonomy); Comment, Towards a Property Right in Employment, 22 Buffalo L. REv. 1081, 1084 (1973) (without restraint on power of dismissal employers exercise dominion over employees' fundamental liberties); see also infra notes 71-72.

69. The observation is not new. The following passage is cited repeatedly in recent articles advocating abandonment of employment at will:

We have become a nation of employees. We are dependent upon others for our means of livelihood, and most of our people have become completely dependent upon wages. If they lose their jobs they lose every resource, except for the relief supplied by the various forms of social security. Such dependence of the mass of the people upon others for all of their income is something new in the world. For our generation, the substance of life is in another man's hands.

F. Tannenbaum, A Philosophy Of Labor 9 (1951) (emphasis in original); see also Reich, supra note 68 , at 739 ("To the individual, ... . a profession, job, or right to receive income ... [is] the basis of . . . status . . . and may therefore be the most meaningful and distinctive wealth he possesses."); Comment, supra note 68, at 1084 (A worker's "job is the basis of his position in society, and, therefore, may be the most meaningful form of wealth he possesses.").

70.

Old conceptions of property limited to the protection of interests in land and physical objects will no longer serve as adequate protection for the individual. Abstractions like jobs must be protected if individual liberty is to survive. Our concept of property must be expanded to encompass the employment relationship, to protect against wrongful discharge.

Comment, supra note 68, at 1085; see also Reich, supra note 68, at 787 (ownership of means of subsistence is increasingly determinative of individual liberty).

71. See NLRB v. Jones \& Laughlin Steel Corp., 301 U.S. 1, 33 (1937); Comment, supra note 68, at 1084, 1093-94; Note, Protecting At Will Employees against Wrongful Discharge: The Duty to Terminate only in Good Faith, 93 HaRv. L. REv. 1816, 1826 (1980) [hereinafter cited as Note, Protecting At Will Employees]; Note, Implied Contract Rights to Job Security, 26 Stan. L. Rev. 335, 337-38 (1974) [hereinafter cited as Note, Implied Contract Rights]. The development of this inequality led to federal protection of the right of self-organization in the NLRA and the growth of the labor movement pursuant to the collective bargaining provisions of the Act. Blades, Employment At Will v's. Individual Freedom: On Limiting the Abusive Exercise of Employer Power, 67 Colum. L. REv. 1404, 1404-05 (1967) ("It is well known that the labor union movement was a response to the imbalance in the relationship of the individual to his employer.").

72. See Blackburn, Restricted Employer Discharge Rights: A Changing Concept of Employment At Will, 17 AM. Bus. L.J. 467 (1980); Blades, supra note 71; Estreicher, At-Will Emplaynent and the Problem of Unjust Dismissal: The Appropriate Judicial Response, 54 N.Y. ST. B.J. 146 (1982); Hermann \& Sor, Property Rights in One's Job: The Case for Limiting Employment-At-Will, 24 ARIZ. L. REv. 763 (1982); Lansing \& Pegnetter, Fair Dismissal Procedures for Non-Union Employees, 20 
ployees not covered by a collective bargaining agreement, ${ }^{73}$ that an employment contract of indefinite length is terminable at the will of either party. ${ }^{74}$ Founded upon the principle of freedom of contract, the at-will rule fundamentally reflects the view that "an employer has a property right of choice concerning whom to employ, for how long, and under what conditions." "76 The rule reached its height in pre-NLRA Supreme Court decisions granting it the status of a constitutionally protected property right. ${ }^{78}$

Contemporary critics of employment at will argue that the assumption of contractual freedom upon which the rule is premised has been rendered obsolete by the declining mobility of the workforce, heightened job insecurity, and increased employee inequality in bargaining power. ${ }^{77}$ They propose to afford jobs the protection of a property right through statutory ${ }^{78}$ or

AM. Bus. L.J. 75 (1982); Murg \& Scharman, Employment At Will: Do the Exceptions Overwhelm the Rule?, 23 B.C.L. REv. 329 (1982); Peck, Unjust Discharges from Employment: A Necessary Change in the Law, 40 OHio ST. L.J. 1 (1979); Peirce, Mann \& Roberts, Employee Termination At Will: $A$ Principled Approach, 28 VILL. L. REv. 1 (1982); Platt, Rethinking the Right of Employers to Terminate At-Will Employees, $15 \mathrm{~J}$. MAR. L. REv. 633 (1982); Summers, supra note 7; Comment, supra note 68; Note, Protecting At Will Employees, supra note 71; Note, Protecting Employees At Will against Wrongful Discharge: The Public Policy Exception, 96 HARv. L. Rev. 1931 (1983); Note, Implied Contract Rights, supra note 71.

73. According to current figures, the proportion of unionized workers in the non-agricultural labor force is just over twenty percent. Weiler, supra note 49 , at 1771-72. Thus the large majority of the American workforce is subject to the employment at will doctrine.

74. Restatement (Second) of Agency § 442 (1958); 9 S. Williston \& W. Jaeger, WillisTON ON CoNTracts $\S 1017$, at $129 \&$ n.11 (3d ed. $1967 \&$ Supp. 1980). The rule is usually traced to the nineteenth century treatise, H. Wood, MASTER AND Servant $\S 134$, at 272 (1877). The atwill rule, which permits the employer "to discharge an employee for good cause, for no cause or even for a bad cause unless the employer relinquished this right by an agreement providing for a definite period of employment," Murg \& Scharman, supra note 72, at 335, is a product of the transformation of the law of employment relations, in the late nineteenth century, from the principally status-oriented master-servant doctrine to the contractual principles of laissez-faire economics. Hermann \& Sor, supra note 72, at 770; M. Glendon, The New Family and The New Property 147-49 (1981). Adopted in a period of rapid industrial expansion in both America, see Lansing \& Pegnetter, supra note 72 , at 77, and Europe, M. Glendon, supra, at 148 , employment at will provided flexibility to entrepreneurs by allowing them to impose the risks of economic transformation on the employee. Murg \& Scharman, supra note 72, at 335-36.

75. Estreicher, supra note 72 , at 147 (emphasis added).

76. Coppage v. Kansas, 236 U.S. 1 (1915) (striking down anti-yellow dog contract legislation that prohibited discharge of employees on the basis of membership in a labor organization). See Blades, supra note 71, at 1417; Summers, supra note 7, at 485-86.

77. Blackburn, supra note 72, at 470: "In an era of high unemployment, the interest of an employee in securing steady employment undermines any theoretical power to freely terminate the employment contract." See Estreicher, supra note 72, at 148-49; Note, Employnent At Will: An Analysis and Critique of the Judicial Role, 68 IowA L. REv. 787, 791-92 (1983).

78. See Estreicher, supra note 72, at 149; Hermann \& Sor, supra note 72, at 812-15; Summers, supra note 7, at 519-32. The legislative proposals typically draw on existing European legislation, inspired by the International Labor Organization Recommendation No. 119, Concerning Termination of Employment at the Initiative of the Employer, 2 ACTS OF THE FIFTH INT'L CoNGRESS OF LABOUR LAW AND Social SEcuRITy (1963). Summers, supra note 7, at 508-19. Of all the countries that had adopted the at-will doctrine, only the United States has not statutorily abolished it. M. Glendon, supra note 74, at 151-52. 
judicial" imposition of a "just cause" standard, prohibiting employers from discharging unorganized employees in the absence of a legitimate business reason. Recent legislative and judicial activity reflects increasing sympathy for this proposal.

Federal and state legislation has progressively limited the actual scope of the employer's power under the at-will rule. The first important such statute, the NLRA, prohibits discharge motivated by an employee's union activity ${ }^{80}$ In declaring the statute constitutional, the Court revoked the atwill rule's status as a constitutionally protected property right of the employer. ${ }^{81}$ Later federal and state statutes have extended the prohibition against discharge to other motives unrelated to the employer's managerial needs. ${ }^{82}$

Gourts are also moving away from a pure at-will regime. Employment at will is a judicial doctrine; while some state courts have declined to recognize exceptions to such a well-settled rule in the absence of a legislative mandate,$^{83}$ most that have considered the issue in recent years have either granted relief based on an exception to the at-will rule or indicated a willingness to recognize exceptions in future cases. ${ }^{84}$

79. Blackburn, supra note 72, at 482-92; Blades, supra note 71, at 1421-35; Protecting At Will Employess, supra note 71, at 1836-44; Note, supra note 72, at 1951; Note, Implied Contract Rights, supra note 71 , at $366-69$.

80. 29 U.S.C. \& 158(a)(3) (1982).

81. NLRB v. Jones \& Laughlin Steel Corp., 301 U.S. 1, 49 (1937) (upholding NLRA's provision forbidding discharge motivated by employee's union activity).

82. The most important of these, Title VII of the Civil Rights Act of 1964, \$§ 701-16, 42 U.S.C. $\$ \S 2000 \mathrm{e}$ to $2000 \mathrm{e}-17$ (1982), prohibits discrimination in employment on the basis of race, religion, nationality, and sex, and has been used to challenge dismissals in a wide variety of cases, as have the similar state statutes and local ordinances that extend Title VII's protection to virtually all public and private employees. Summers, supra note 7, at 493 . At the federal level, Title VII is supplemented by legislation prohibiting discharges based on age, Age Discrimination in Employment Act of 1967, $\S \S$ 1-16, 29 U.S.C. $\$ \S 621-34$ (1982), and by several more specialized provisions. These provisions include protection of employees against dismissals resulting from the garnishment of wages for indebtedness, Consumer Credit Protection Act of 1968, § 304, 15 U.S.C. $\$ 1674$ (1982), or the exercise of rights guaranteed by the Fair Labor Standards Act of 1938, § 15(3), 29 U.S.C. $\S 215(3)$ (1982), and the Occupational Safety and Health Act of 1970, $\S 11,29$ U.S.C. $\S 660$ (c) (1982).

At the state level, in addition to the protections against employment discrimination noted above, there are a variety of statutory limits on employers' power of discharge. At least fifteen states have legislation similar to the NLRA. Summers, supra note 7, at 492. A number offer statutory protection against discharge designed to coerce employee voting, id. at 495 , or political activity more broadly defined, id., or against discharge in retaliation for filing a worker's compensation claim, Peirce, Mann \& Roberts, supra note 72, at 13, serving on a jury, LAB. L. REP. (State Laws) (CCH) I 43,035, refusing to take a lie detector test, $i d$. $\ 43,055$, or reporting or participating in the investigation of a reported violation of federal, state, or local law. Whistleblowers' Protection Act, Mich. CoMP. LAws ANN. \$15.362 (1981).

83. See Hinrichs v. Tranquilaire Hosp., 352 So.2d 1130, 1131-32 (Ala. 1977); Ivy v. Army Times Publishing Co., 428 A.2d 831, 831 (D.C. App. 1981).

84. The first major case in the development of judicial recognition of exceptions to the at-will rule was Petermann v. Teamsters Local 396, 174 Cal. App. 2d 184, 189-90, 344 P.2d 25, 28 (1959). Since Petermann, courts in twenty-four states have recognized exceptions to the rule. See Naylor, Employment at Will: The Decay of an Anachronistic Shield for Employers?, 33 DRAKE L. REv. 113, 117 \& n.15 (1983-1984). 
Some courts have departed radically from employment at will, authorizing causes of action with far-reaching implications for the creation of an employee job property right. For example, in Monge v. Beebe Rubber Co. ${ }^{85}$ the New Hampshire Supreme Court granted relief to a plaintiff who claimed that she had been discharged for refusing to date her foreman; the court found the employer in breach of an implicit contractual covenant of good faith and fair dealing. ${ }^{86}$ Were courts to imply such a

Courts in at least three other states have indicated a willingness to recognize an exception to the atwill rule while rejecting the claim presented in the particular case. Abrisz v. Pulley Freight Lines, 270 N.W.2d 454, 456-57 (Iowa 1978); Mau v. Omaha Nat'l Bank, 207 Neb. 308, 316-17, 299 N.W.2d 147, 151-52 (1980); Jones v. Keogh, 137 Vt. 562, 564, 409 A.2d 581, 582 (1979).

These courts agree on the need to place limits on the employer's power under the at-will rule; they differ only as to how large an exception to carve out and whether to base it on tort or contract principles. See Note, supra note 72 , at 1935 . In fact, as the commentators demonstrate, maximum job security consistent with recognition of the employer's managerial needs can be achieved on either tort or contract grounds through judicial imposition of a "just cause" standard governing dismissals. In tort, the cause of action may proceed upon the theory that any discharge, absent just cause, violates the public policy of ensuring stability of employment. See Note, Protecting At Will Employees, supra note 71, at 1833-34; Note, supra note 72 , at 1950 . Contractual imposition of a just cause standard may proceed in two ways: through the implication of a contractual just cause provision based upon legitimate employee expectations, or by holding that all employment contracts contain implied covenants of good faith and fair dealing that preclude dismissal absent just cause.

The early judicial exceptions to employment at will were in tort and predicated upon employer violation of an explicit state public policy. See Tameny v. Atlantic Richfield Co., 27 Cal. 3d 167, 172, 610 P.2d 1330, 1332-33, 164 Cal. Rptr. 839, 841-42 (1980) (discussing cases in which public policy exception was created). The public policy exception has been applied in three separate categories of cases: (1) discharges in retaliation for refusal to commit an illegal act; (2) discharges in retaliation for exercise of a statutory right; (3) discharges in retaliation for whistle blowing activity. Bakaly, Erosion of the Employment At-Will Doctrine, 8 J. CoNTEMP. L. 63, 69-73 (1982). Other public policy cases are predicated upon a direct harm to the employee. One line of cases recognizes an exception to the at-will rule for employees discharged in retaliation for filing a worker's compensation claim. See Kelsay v. Motorola, Inc., 74 Ill. 2d 172, 181-86, 384 N.E.2d 353, 357-59 (1978); Frampton v. Central Indiana Gas Co., 260 Ind. 249, 252-53, 297 N.E.2d 425, 428 (1973); Sventko v. Kroger Co., 69 Mich. App. 644, 646-49, 245 N.W.2d 151, 153-54 (1976). See also Novosel v. Nationwide Ins. Co., 721 F.2d 894, 898-900 (3d Cir. 1983) (recognizing, under Pennsylvania law, cause of action based on violation of associational freedom guaranteed by state and federal constitutions).

A growing number of cases adopt a contractual theory, typically implying a just cause for dismissal term by incorporating into the contract statements in employer policy manuals or other representations of continuing employment made to the employee. For example, in Yartzoff v. Democrat-Herald Publishing Co., 281 Or. 651, 576 P.2d 356 (1978), the employee received a handbook, two days after hire, but on the first day of work, which described grounds for termination during the initial probationary period of employment; the Oregon Supreme Court held that a jury could consider the grounds stated in the handbook as part of the employment contract. Id. at 654-58, 576 P.2d at 358-60; see also Pugh v. See's Candies, 116 Cal. App. 3d 311, 329, 171 Cal. Rptr. 917, 927 (1981) (personnel policies or practices of employer sufficient to bind employer to just cause standard); Cleary v. American Airlines, 111 Cal. App. 3d 443, 455-56, 168 Cal. Rptr. 722, 729 (1980) (length of service and personnel policy of employer); Toussaint v. Blue Cross \& Blue Shield, 408 Mich. 579, 613-15, 292 N.W.2d 880, 891-92 (1980) (supervisory manual and oral representation of personnel policies); Weiner v. McGraw-Hill, 57 N.Y.2d 458, 460-61, 465-66 (1982) (policy manual and oral representation of employer). While these cases predicate the cause of action on the employee's own interest in job security, the contract approach is open to frustration through express contractual reservation of the employer's right to discharge without cause. See Note, supra note 72, at 1935.

85. 114 N.H. 130, 316 A.2d 549 (1974).

86. Id. at 133,316 A.2d at 551. The Monge court also noted that limits on the employer's power under employment at will were necessary in view of the public's interest in employment security.

The Supreme Judicial Court of Massachusetts has also granted relief on the basis of such an 
covenant in all employment contracts, they would effectively impose a just cause standard for dismissal of unorganized employees.

Erosion of the at-will rule indicates that courts have reconceptualized the employment relationship. This reconceptualization acknowledges both employees' and the public's interest in job security, and leads to protection of that interest through elimination of the employer's right to make arbitrary or discriminatory decisions regarding job tenure. Thus the New Hampshire Supreme Court reasoned, in Monge, that: "In all employment contracts, whether at will or for a definite term, the employer's interest in running his business as he sees fit must be balanced against the interest of the employee in maintaining his employment, and the public's interest in maintaining a proper balance between the two." ${ }^{87}$ Whether statutory or judicial, proposals to eliminate at-will employment balance managerial needs against job security, and permit the employer to dismiss for cause. ${ }^{88}$

\section{Conclusion}

Continued recognition of the Babcock doctrine seriously and unjustifiably limits the reach of an emerging balance between employees' interest in job security and the employer's managerial prerogative. The NLRA enables employees to protect their jobs against dismissal without cause through self-organization. Both the burdening of union and employer rights in administration of the Act and the recent trend towards protection of unorganized employees against unjust dismissal display an enhanced appreciation of the value of employment security. If this value is to be adequately protected, courts must free the employee right of selforganization from the constraints imposed by Babcock.

The Supreme Court should overrule Babcock, and revive the standards articulated in Republic Aviation to regulate nonemployee solicitation. ${ }^{89}$ These standards can be flexibly applied ${ }^{90}$ to allow employees to discuss organization at the most meaningful location, the workplace, with the nonemployee organizers who possess information critical to the choice re-

implied covenant, Fortune v. National Cash Register Co., 373 Mass. 96, 101, 364 N.E.2d 1251, 1255-56 (1977), and a recent California case holds that a covenant of good faith and fair dealing is implicit in all employment contracts, Cleary v. American Airlines, 111 Cal. App. 3d 443, 455, 168 Cal. Rptr. 722, 729 (1980).

87. 114 N.H. at 133,316 A.2d at 551 .

88. Hermann \& Sor, supra note 72, at 815-16; Peck, supra note 72, at 48-49; Peirce, Mann \& Roberts, supra note 72, at 45; Summers, supra note 7, at 501-08; Comment, supra note 68, at 1108-09; Note, Protecting At Will Employees, supra note 71, at 1840; Note, Implied Contract Rights, supra note 71 , at 366-69.

89. 324 U.S. at 803 n.10 (quoting Peyton Packing Co., 49 N.L.R.B. 828, 843-44 (1943)). See supra notes 11-13 and accompanying text.

90. See supra note 22 and accompanying text for a discussion of the flexible application of these standards in the context of retail businesses. 


\section{Workplace Solicitation}

garding unionization. By limiting routine access of nonemployee organizers to parking lots and nonsensitive plant areas, while ensuring a reasonable opportunity for nonemployee organizers to respond in kind to employer captive audience speeches, these standards make meaningful nonemployee solicitation possible without compromising the legitimate managerial interests of employers. ${ }^{91}$

-Sarah Korn

91. This approach also justifies loosening the restrictions currently imposed on employer campaign activities. Nonemployee access to company property would counteract the employer's great advantage in communicating with employees during the campaign, thus legitimating an enlargement of the sphere of employer campaign speech protected by the First Amendment. The converse of this proposition was stated in UNION REPRESENTATION ELECTIONS, supra note 47, at 157:

An opportunity for unions to respond on company premises to anti-union campaigning on those premises is particularly important if the Board, as we recommend, is to cease regulating speech. Campaign regulation in political elections is based on the assumption that each party will be able to point out to the voters those aspects of the other party's campaign it believes to be untruthful or unfair. Unions will have that ability only if they have the opportunity to campaign on equal terms with the employer on company premises. 